INTERDISCIPLINARIA ARCHAEOLOGICA NATURAL SCIENCES IN ARCHAEOLOGY

\title{
A Case for Coexistence of Different Potting Practices - Baltic Ware in Latvia
}

\author{
Alise Gunnarssone ${ }^{1 *}$, Baiba Dumpe ${ }^{1}$, Vanda Visocka ${ }^{1}$, Artūrs Brēḳis ${ }^{2}$ \\ ${ }^{1}$ National History Museum of Latvia, Pulka 8, Rīga, Latvia \\ ${ }^{2}$ Institute of Physics of the University of Latvia, Miera street 32, Salaspils, Latvia
}

\section{A RTICLE INFO}

\section{Article history:}

Received: $15^{\text {th }}$ January 2021

Accepted: $5^{\text {th }}$ August 2021

DOI: http://dx.doi.org/10.24916/iansa.2021.2.9

Key words:

Baltic ware

wheel-coiled pottery

potter's wheel

ceramic manufacturing technique

Late Iron Age

the Baltics

Reflectance Transformation Imaging (RTI)

\begin{abstract}
A B S T R A C T
Latvia in the $11^{\text {th }}-13^{\text {th }}$ century poses a curious case for the coexistence of two different practices of Baltic ware production. The Baltic ware pots from lower reaches of the River Daugava and from the Courland region look not just stylistically, but also technologically different. Our paper assessed the production traces by using macro-observations, Reflectance Transformation Imaging (RTI) and extensive ethnographic material of Slavic pottery production of the 1900s, as well as using modern replicas as visual aids to assist in the identification of the principal coil attachment methods.

The results showed that potters from the lower reaches of Daugava used the wheel's rotation extensively during the shaping process of Baltic ware. The production of the pots required the potter to possess a level of technical skill which implied a level of professionalisation. Baltic ware from Courland was less technically complicated and used comparatively more of the methods of handmade pottery production.
\end{abstract}

\section{Introduction}

It is a well-established belief in the current scholarship that Baltic ware pottery was made primarily by using the methods of handmade pottery production with the assistance of a turntable surface (Roslund, 2007, pp.160 and 171). Although many archaeologists have opposed a separation of "slow" and "fast" potters' wheels (Berg, 2020 pre-print, pp.4-6; Rice, 2005, pp.133-134; Eiteljorg, 1980, pp.447-449; Rückl and Jacobs, 2016, p.298), it still plays a major role in how we discuss pottery (Roux and de Miroschedji, 2009, p.155) and is used as a defining feature of this pottery type without much further discussion. However, the general technical features of the local Baltic ware display a great variation between two regional production techniques, showing it as a more complex and multifaceted group of pottery.

Ethnographic material already shows us that wheel coiled Baltic ware pots were not a monogamous group but contained variation both in the tools and methods used by the

*Corresponding author. E-mail: alise.gunnarssone@gmail.com potter. This paper aims to understand Baltic ware production in two regions that display a surprising difference in the finished product. The paper looks to: do a primary review of the technological features of the pots (pot dimensions, wall thickness, coiling technique); examine the production traces in more detail than has been done previously; compare and contrast the production traces found on Daugava and Courland Baltic ware; correlate the production traces with applicable wheel-coiled pottery production techniques known in ethnography; and attempt to clarify the underlying reasons for the different pottery production modes, based on applicable ethnographic material.

\section{Material, methodology and theoretical bases}

\subsection{Material selection}

To compare the Baltic ware pottery of Courland and that of the lower reaches of the River Daugava we chose material from Talsi hillfort and the Salaspils Laukskola cemetery. During the Late Iron Age, the lower reaches of Daugava were inhabited by the Livs. Beginning with the $11^{\text {th }}$ century, 
they adopted the Slavic pottery tradition, i.e. Baltic ware. By the end of the $13^{\text {th }}$ century, it had become the dominant household and burial pottery (Šulte et al., 2017, p.14; Gunnarssone et al., 2020, p.58).

Out of the 610 burials excavated at Salaspils Laukskola cemetery ( $11^{\text {th }}-13^{\text {th }}$ century), 302 contained pottery, 167 of these being Baltic ware (Zarina, 2006, pp.307 and 463; Šulte et al. 2017, p.13). As this has been shown to be a secondary use of household pottery (Gunnarssone et al., 2020, pp.58 and 64), it is representative of the general tradition.

The sample selection was restricted to 38 samples, based on the preservation of the material traces. We concentrated on pots with fully preserved bottoms but missing shoulder and rim parts. This allowed for quality pictures of production traces using RTI. We also included pots that had broken vertically in half. Fully preserved pots were used to assess height and general shape of this pottery type.

In Courland, the available material was less abundant. The amount of ceramic material from settlements in Courland has always been smaller than any comparative site of other regions (Vasks et al., 2011, p.92.; Sulte, 2011, pp.47-51). In addition, handmade pottery was still in use (Kraukle, 2011, p.69). The restricted material base forced a smaller sample size. Luckily, production traces, such as draglines, imprints from shaping, etc., were well identifiable on the sherds analysed.

During the $11^{\text {th }}-13^{\text {th }}$ century, Courland was home for two populations - the Vends and the Couronians (Asaris et al., 2008, p.138). Talsi hillfort $\left(10^{\text {th }}-13^{\text {th }}\right.$ century, to a lesser extent till the $15^{\text {th }}$ century) was part of their relations (Asaris, 2001, p.70; Asaris and Tora, 1994, pp.19-22; Kraukle, 2011, pp.74-77). The pottery of Talsi contained both sherds from Baltic ware types generally common in Latvia, but also sherds unique to Courland. This article focuses on the local variants. It should be noted that, although the ornamentation of the Talsi Baltic ware pots was unique, the general shaping technique and proportions seem consistent with the rest of Courland (Šulte, 2011, p.35).

For a detailed examination, we chose four samples of Baltic ware sherds, containing both the base and the walls. Sherds from the upper parts of pots we examined in detail when they could be related to a specific bottom sherd.

\subsection{Methods}

In this study the general proportions of the pots were assessed in the typical measurements of height, diameter of rim, and base and wall thickness. To make the identification of the coil attachment methods used in our material more convenient, we created a visual aid - three sample pots made with three principal coil attachment methods. The samples represent coil attachments from either side of the vessel and from the top. These attachment methods are well known both in handmade pottery (see Piličauskas, 2018, p.123; Dumpe, 2007, pp.36-37) and in the Baltic ware of other regions (see Griežiene, ed., 2011, pp.22-24). The bases of the vessels were made as a flat disc. These visual aides were not intended for an in-depth comparative analysis of the surface production traces noted in our archaeological material, but only to aid in the correct identification of the coil attachment principle used, taking into account the distortions introduced by the latter shaping process.

Although previously we have made Baltic ware replica pots on a hand-driven potter's wheel, these pots were shaped on a foot-driven potter's wheel. The diameter of the flywheel was the same as the head $-24 \mathrm{~cm}$. The weight of the rotating part was $14 \mathrm{~kg}$. For comparison, the diameter of the hand-driven wheel's head was $33 \mathrm{~cm}$, weight $9 \mathrm{~kg}$. As is traditional for the region, both flywheels were solid wood (Figure 10). In this case the inertia $\left(\mathrm{J}=\mathrm{mxR} \mathrm{R}^{2}\right)$ available to the potter on this footdriven potter's wheel was less than would be for the handdriven potter's wheel. The shaping was done by a professional potter/archaeologist with the help of a potter's rib.

To produce these replicas, two different commercial clays (local Quaternary and white clay from Germany) were used. Using this type of clay allowed us to use different colours (red and white) to make the connections of clay coils more visible. Typically, as for Baltic ware, the clays were mixed with small to medium fragments of burned and crushed granite (Dumpe, 2021, p.503). In our case, these inclusions reached up to $2 \mathrm{~mm}$. No other specific clay preparation has been noted so far in the archaeological research of local pottery.

Notably, clay is the most common material in the territory of Latvia; therefore, it was and is easily accessible (see Kuršs and Stinkule, 1972; Stinkule, 2014). In the territory of lower Daugava, where Laukskola was located, Devonian and moraine clay is common (Kuršs and Stinkule, 1972, pp.27-44; Visocka et al., 2021, p.12). Whereas in Courland, various Quaternary clay deposits and moraine clay is common, Devonian clay in this region being only common on the South shore of Courland, for example, Jūrkalne and Labrags (Kuršs and Stinkule, 1972, pp.48-75; Visocka et al., 2021, p.12). There is no detailed research of how clay quality could have affected the quality of the pots in the two study regions; however, it is known that there are qualitative clay beds in the surroundings of the sites analysed.

After a week of drying, we fired the pots in approximately $750{ }^{\circ} \mathrm{C}$ in a $11^{\text {th }}-12^{\text {th }}$ century replica kiln (Dumpe, 2009, pp.73-74). When the pots sufficiently cooled down, we broke them vertically in half (Figure 1).

To assess the technological aspects of the coiling and shaping of the archaeological pottery in detail we looked at the production traces visible on the surface. For determining the production traces on the vessel surface, we used Reflectance Transformation Imaging (RTI). It allowed us to create topographic models of these aspects. RTI was applied to eight vessels from Laukskola cemetery and four from Talsi hillfort.

RTI is a photographic method that captures surface features by photographing a fixed artefact and illuminating it from different angles. This results in creating a threedimensional virtual surface topography of the artefact from multiple combined photographs. This study used the highlight RTI method. The visualizations of the samples 
Figure 1. Baltic ware pot replicas made by Baiba Dumpe in 2020. 1 - coils attached from the inside, 2 - coils attached from the top, 3 - coils attached from the outside.

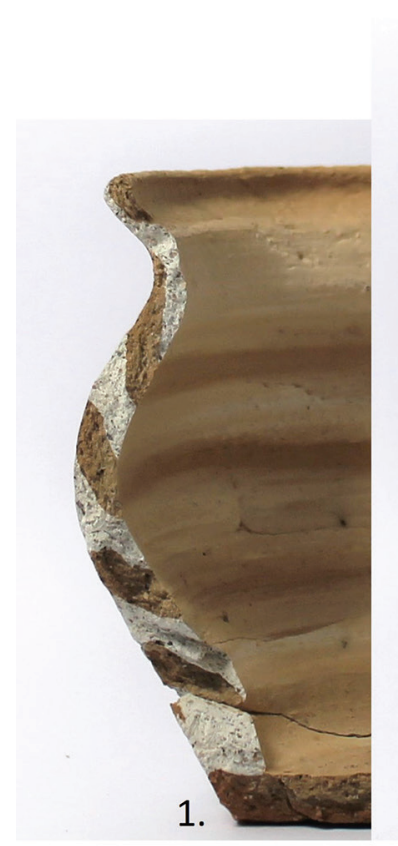

1.

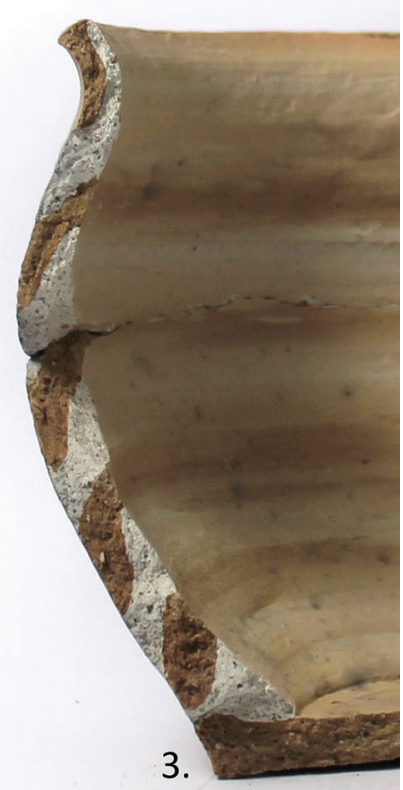

2.

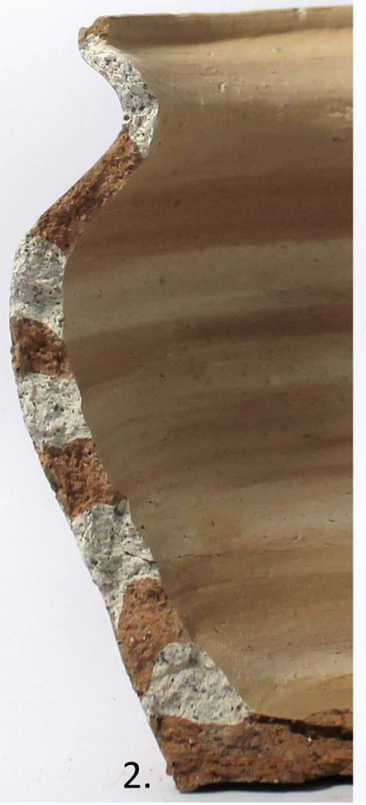

$1 \mathrm{~cm}$ we made following the Cultural Heritage Imaging (CHI) guidelines of RTI highlight image capture (CHI, 2020).

Each sample was manually illuminated from angles of $15^{\circ}$ to $65^{\circ}$, with additional specific angles for individual features. We took an average of 50 photos of each sample. All illumination angles were with an average distance of $40 \mathrm{~cm}$ from the object. Photos were taken in RAW and processed in JPEG image format. For processing of the images, we used RTIBuilder - and for viewing the results, RTIViewer, provided by $\mathrm{CHI}$.

To interpret the production traces revealed by the RTI we put a large emphasis on the previously gathered and analysed ethnographic material. Often for analyses of western wheelcoiled pottery this is done using the outline of the four methods of wheel-fashioning by Roux and Courty (Roux and Courty, 1998, pp.748-750). In this study, we chose to use ethnographic research by A. A. Bobrinsky on the stepwise adoption of the potter's wheel in the Slavic regions (Bobrinsky, 1978, p.27). For this material it was more applicable, as it dealt with this particular pottery type. Based on archaeological and ethnographic material, Bobrinsky has separated seven stages of the use of the potter's wheel in Slavic pottery:

1. potter's wheel was used as a rotating table to assist in the hand shaping of pots;

2. potter's wheel was used to smooth out the surface of an already-constructed, hand-made pot;

3 . in addition to smoothing out the surface, the potter's wheel was used for partial profiling of the rim, while the rest of the pot was made by hand;

4. potter's wheel was used for partial or full shaping of the pot (neck, shoulders, body) after a clay cylinder was constructed by hand;

5. potter's wheel was used to smooth out, shape, and also to partially pull up the pot from a clay cylinder that was constructed by hand;
6. potter's wheel was partially used to shape a base cylinder and to pull a pot up. However, the pot was still attached to the wheel's surface by hand or other hand techniques were used in the process;

7. potter's wheel was used to pull a pot from one lump of clay. (Bobrinsky, 1978, p.27)

The ethnographic material was further used to not only clarify the production methods, but also examine other questions about the craft and pottery specialisation in the discussed regions. The ethnographic research undertaken primarily by Bobrinsky systemised not only the different production methods for this pottery type, but showed how it statistically linked with the tools used, the professionalisation of the potter, his/her productivity, and much more (see Table 3; see Bobrinsky, 1978). This basis allowed hypotheses to be formed on the possible level of crafts development in the given regions.

\section{Results}

\subsection{Daugava Baltic ware}

The height of Baltic ware pots from Daugava was generally between $10-15 \mathrm{~cm}$. Outliers ranged from $6 \mathrm{~cm}$ to $20.5 \mathrm{~cm}$ height (Figure 2). The thickness of a pot wall varied in the range $0.4-0.8 \mathrm{~cm}$ (Table 1). The largest vessel (height of $20.5 \mathrm{~cm}$ ) had a wall thickness of $0.6-0.7 \mathrm{~cm}$ (measured at the shoulder).

Although the outside surface of all the pots was always fully smoothed out, the inside could display a variety of production traces. The inside surface of the top two-thirds of the pots was typically fully smoothed out - only rare traces of coils could be distinguished. However, 20 pots had visible finger impressions from pressing these coils together on the 


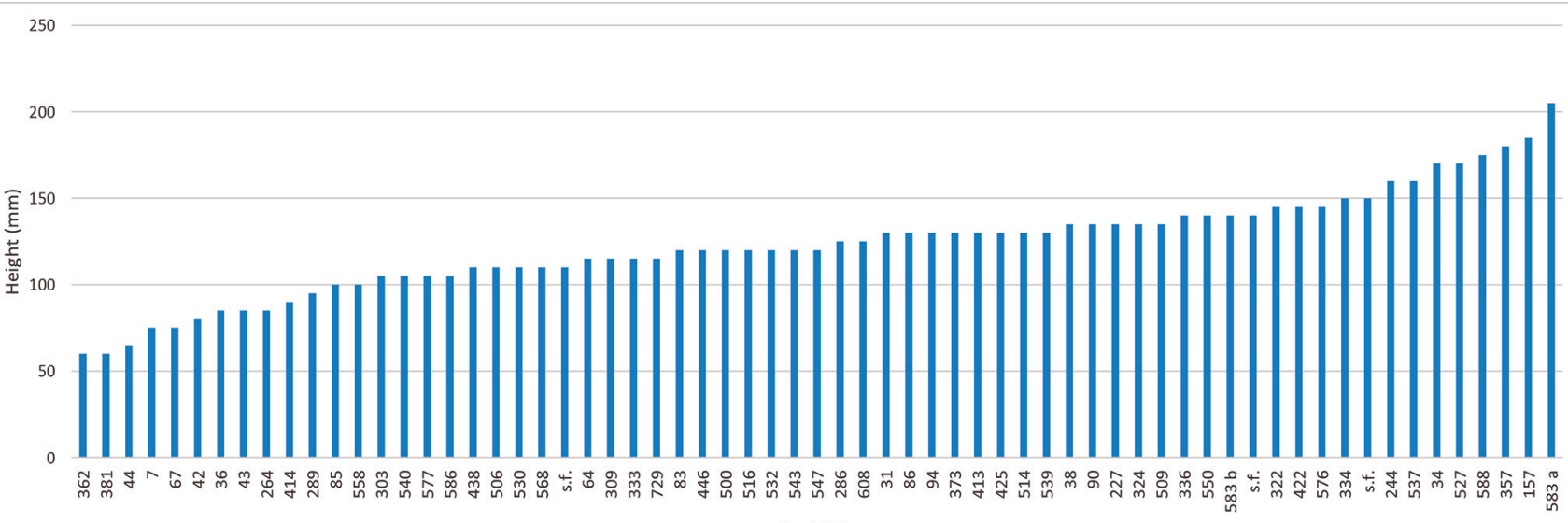

Burial No

Figure 2. Variation of Baltic ware vessel height in Salaspils Laukskola cemetery.
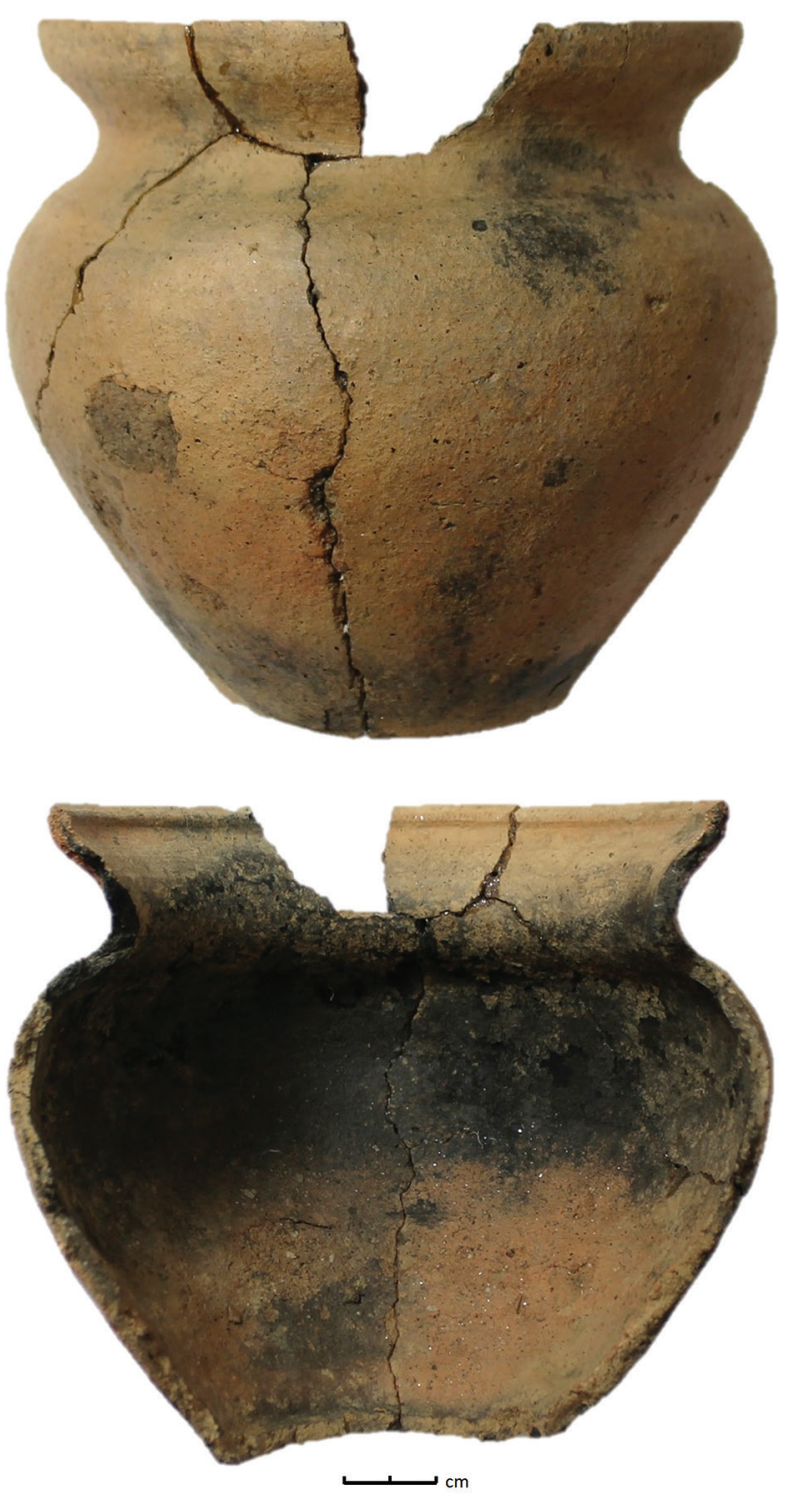

Figure 3. Baltic ware pot from Salaspils Laukskola cemetery, feature No 100. inside surfaces (Figures 3 and 4, Table 1). The corresponding traces on the outside of the pots were absent. In some cases, the finger impressions had possibly warped - indicating in which direction the potter's wheel could have rotated (Figure 5).

Other production traces on the inside surfaces were horizontal draglines created during the rotation of the wheel. The draglines on the inside surface covered the whole pot, including the base. The draglines on the walls were consistently horizontal and with few noted interruptions or stops. In some cases, the draglines formed a circle on the inside surface of the pot base (Figure 5).

Out of the 38 examined pots, two had clear traces of vertical draglines (Table 1). These were layered on top of the horizontal draglines. They were seemingly created by the potter attempting to straighten the vessel and correct for a previous error.

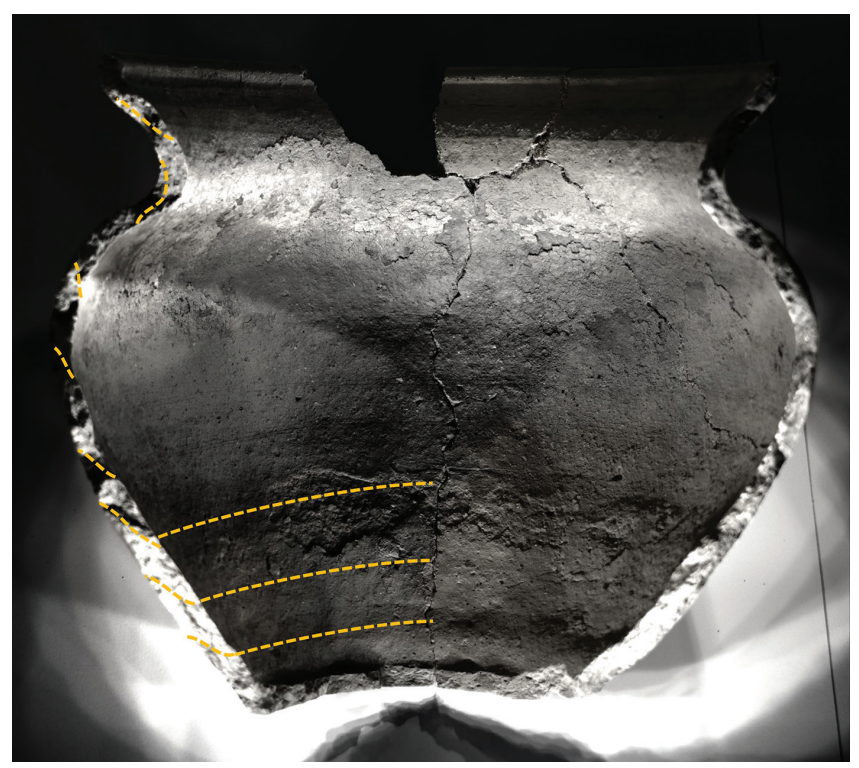

Figure 4. Baltic ware pot in RTIViewer from Salaspils Laukskola cemetery, feature No 100; with approximation of coil attachments. 
Table 1. Production traces and wall thickness of burial pottery from Laukskola cemetery.

\begin{tabular}{|c|c|c|c|c|}
\hline Burial No & Wall thickness (mm) & Horizontal lines & Vertical lines & Finger impressions \\
\hline 84 & $5.9-5.3$ & $\mathrm{x}$ & - & $\mathrm{x}$ \\
\hline 120 & $5.4-5.3$ & $\mathrm{x}$ & - & - \\
\hline 121 & $6.8-4.1$ & $\mathrm{x}$ & - & $\mathrm{x}$ \\
\hline 128 & - & $\mathrm{x}$ & - & - \\
\hline 136 & $6.0-4.3$ & $\mathrm{x}$ & - & $\mathrm{x}$ \\
\hline 153 & $7.3-5.2$ & $\mathrm{x}$ & - & $\mathrm{x}$ \\
\hline 165 & $5.9-5.6$ & $\mathrm{x}$ & - & $\mathrm{x}$ \\
\hline 169 & $6.7-5.4$ & $\mathrm{x}$ & - & $\mathrm{x}$ \\
\hline 176 & $4.6-4.2$ & $\mathrm{x}$ & - & $\mathrm{x}$ \\
\hline 177 & $5.1-5.1$ & $\mathrm{x}$ & - & - \\
\hline 185 & $7.2-5.3$ & $\mathrm{x}$ & - & $\mathrm{x}$ \\
\hline 191 & $7.4-5.8$ & $\mathrm{x}$ & - & $\mathrm{x}$ \\
\hline 193 & $6.1-3.8$ & $\mathrm{x}$ & - & - \\
\hline 196 & $6.7-5.9$ & $\mathrm{x}$ & - & $\mathrm{x}$ \\
\hline 202 & $4.9-4.1$ & $\mathrm{x}$ & - & $\mathrm{x}$ \\
\hline 204 & $5.4-4.9$ & $\mathrm{x}$ & - & $\mathrm{x}$ \\
\hline 231 & $8.4-4.4$ & $\mathrm{x}$ & - & - \\
\hline 238 & - & $\mathrm{x}$ & - & - \\
\hline 341 & $6.0-4.5$ & $\mathrm{x}$ & $\mathrm{x}$ & $\mathrm{x}$ \\
\hline 414 & $6.3-4.4$ & $\mathrm{x}$ & - & - \\
\hline 444 & $6.8-5.1$ & $\mathrm{x}$ & - & - \\
\hline 445 & $8.1-6.8$ & $\mathrm{x}$ & $\mathrm{x}$ & $\mathrm{x}$ \\
\hline 478 & $8.0-6.1$ & $\mathrm{x}$ & - & - \\
\hline 491 & $6.3-4.3$ & $\mathrm{x}$ & - & - \\
\hline 498 & $6.6-5.6$ & $\mathrm{x}$ & - & $\mathrm{x}$ \\
\hline 513 & $6.1-5.6$ & $\mathrm{x}$ & - & $\mathrm{x}$ \\
\hline 514 & $6.3-4.1$ & $\mathrm{x}$ & - & - \\
\hline 528 & $6.4-6.3$ & $\mathrm{x}$ & - & $\mathrm{x}$ \\
\hline 541 & $6.0-4.6$ & $\mathrm{x}$ & - & $\mathrm{x}$ \\
\hline 546 & - & $\mathrm{x}$ & - & $\mathrm{x}$ \\
\hline 569 & $6.5-4.1$ & $\mathrm{x}$ & - & - \\
\hline 576 & $6.5-4.5$ & $\mathrm{x}$ & - & $\mathrm{x}$ \\
\hline 577 & $8.5-5.3$ & $\mathrm{x}$ & - & - \\
\hline 593 & $8.5-3.9$ & $\mathrm{x}$ & - & - \\
\hline 595 & $7.0-5.5$ & $\mathrm{x}$ & - & - \\
\hline feature 100 & $7.5-4.5$ & $\mathrm{x}$ & - & - \\
\hline stray find & $6.6-5.6$ & $\mathrm{x}$ & - & - \\
\hline stray find & $7.9-5.3$ & $\mathrm{x}$ & - & - \\
\hline
\end{tabular}

In some cases, the outside surface of the pots had preserved impressions of a potter's rib (Figure 6). Wooden and bone shaping tools (boards, knifes, templates) are well known in ethnography and archaeologists have found some of these in excavated pottery workshops of the same time period (Tvauri, 2000, p.23; Griežiene, ed, 2011, pp.17-18; Bobrinsky, 1978, p.52).

\subsection{Courland Baltic ware}

In Courland the Baltic ware had a bottom diameter of $8-10 \mathrm{~cm}$ (Table 2). The wall thickness tended to gradually thin out from the bottom to the top of the pot. The base, as the thickest part of the pot, ranged from $1.1-1.7 \mathrm{~cm}$. The walls at the bottom ( $2 \mathrm{~cm}$ from the ground) reached $0.9-1.4 \mathrm{~cm}$. They gradually thinned down, at $3 \mathrm{~cm}$ from the ground reaching 
Table 2. Technical measurements of Baltic ware from Talsi hillfort.

\begin{tabular}{ccccc}
\hline Inventory No. & Base diameter (cm) & Base thickness (mm) & $\begin{array}{c}\text { Wall thickness } \\
\text { approximately } \mathbf{~ c m} \\
\text { from the base (mm) }\end{array}$ & $\begin{array}{c}\text { Wall thickness } \\
\text { approximately } \mathbf{3} \mathbf{~ c m} \\
\text { from the base }(\mathbf{m m})\end{array}$ \\
\hline A 11431: 2994 & 10 & 17 & 12 & 9 \\
A 11431: 2962 & 8 & 12 & 9 & 8 \\
A 11431: 2991 & 10 & 15 & - & - \\
A 11431: 2994 & 10 & 15 & 14 & 10 \\
A 11431: 2918 & 8 & 13 & 10 & 10 \\
A 11431: 2923 & 8 & 15 & 11 & 10 \\
\hline
\end{tabular}

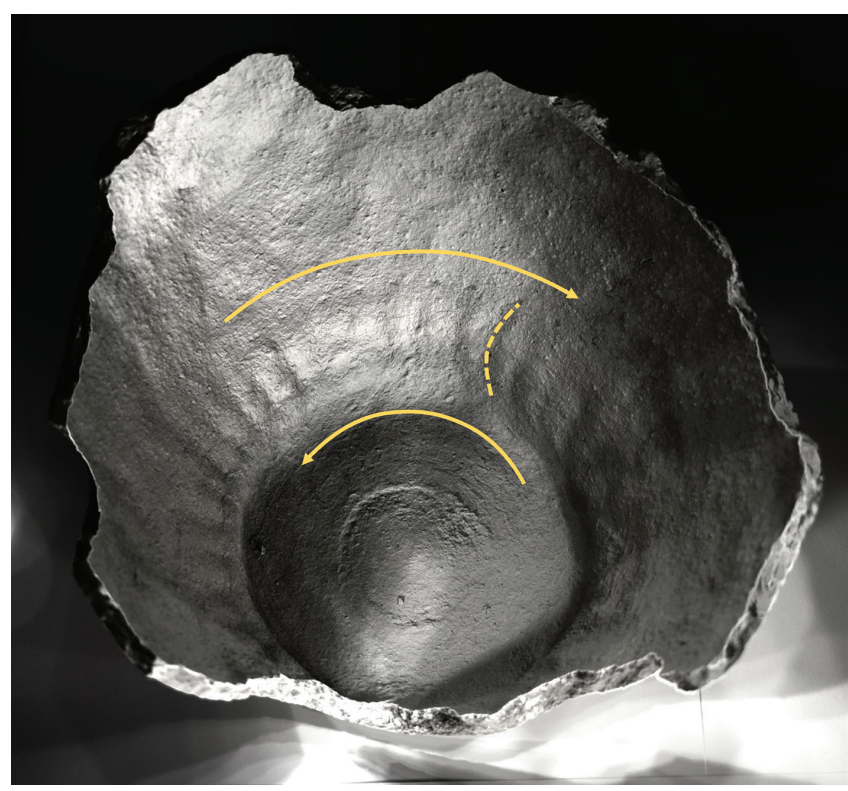

Figure 5. Baltic ware pot bottom in RTIViewer from Salaspils Laukskola cemetery, burial No 478; with noted finger impressions and possible rotation/drag directions.

$0.8-1.0 \mathrm{~cm}$ thickness. This progression seemed to continue as the rim sherds were all much thinner, at the thinnest (shoulder) approximately $0.4 \mathrm{~cm}$.

The bottoms of the pots had well integrated clay coils. The potter had fully smoothed them out on the inside and outside (Figure 7:1). However, the coils could still be noted on the fracture (Figure 8).

The inside surface of the pot bottoms had a variety of draglines (Figure 7:2). Some were more horizontal and could have been created by the potter using the wheel's rotation. The longest visible horizontal dragline extended for $2 / 3$ of the pot's circumference. Other draglines were more diagonal or curved and were in line with the hand movements from producing handmade pottery.

We were able to schematically reconstruct one Baltic ware pot found in building E, of which the archaeologists had collected multiple sherds (Figure 8 ). The diameter of the rim was $14 \mathrm{~cm}$ and the diameter of the base was $8 \mathrm{~cm}$. The hypothetical height was $14 \mathrm{~cm}$. There was a notable, gradual thickening of the walls towards the base. The base was

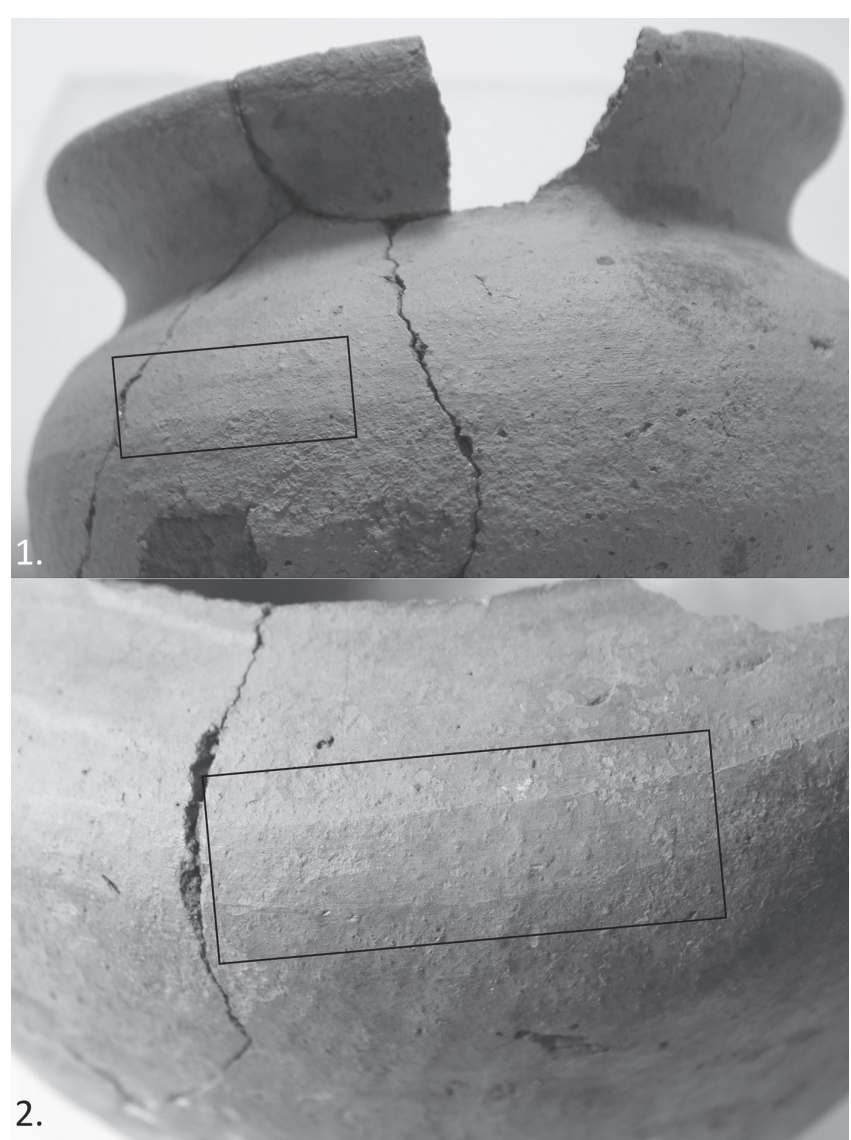

Figure 6. Baltic ware pots from Salaspils Laukskola cemetery: 1 - feature No 100,2 - burial No 582 .

$1.3 \mathrm{~cm}$ thick, the wall approximately $2 \mathrm{~cm}$ from the ground was $1.1 \mathrm{~cm}$ thick, and $6 \mathrm{~cm}$ from the ground the wall was $0.8 \mathrm{~cm}$ thick. The thickness of the top of the shoulder was $0.4 \mathrm{~cm}$ and the neck was $0.8 \mathrm{~cm}$ thick. Hence, the thickest part was the base, but the thinnest was the bottom part of the shoulder.

The inside of the bottom sherd of this schematically reconstructed pot had horizontal draglines with several interruptions. The lower diagonal draglines were from an ending of a stroke that had circled the base (Figure 9). The top diagonal draglines were similar but were overlayed by other lines. The rim sherd of the same pot had more consistently horizontal, uninterrupted draglines. 

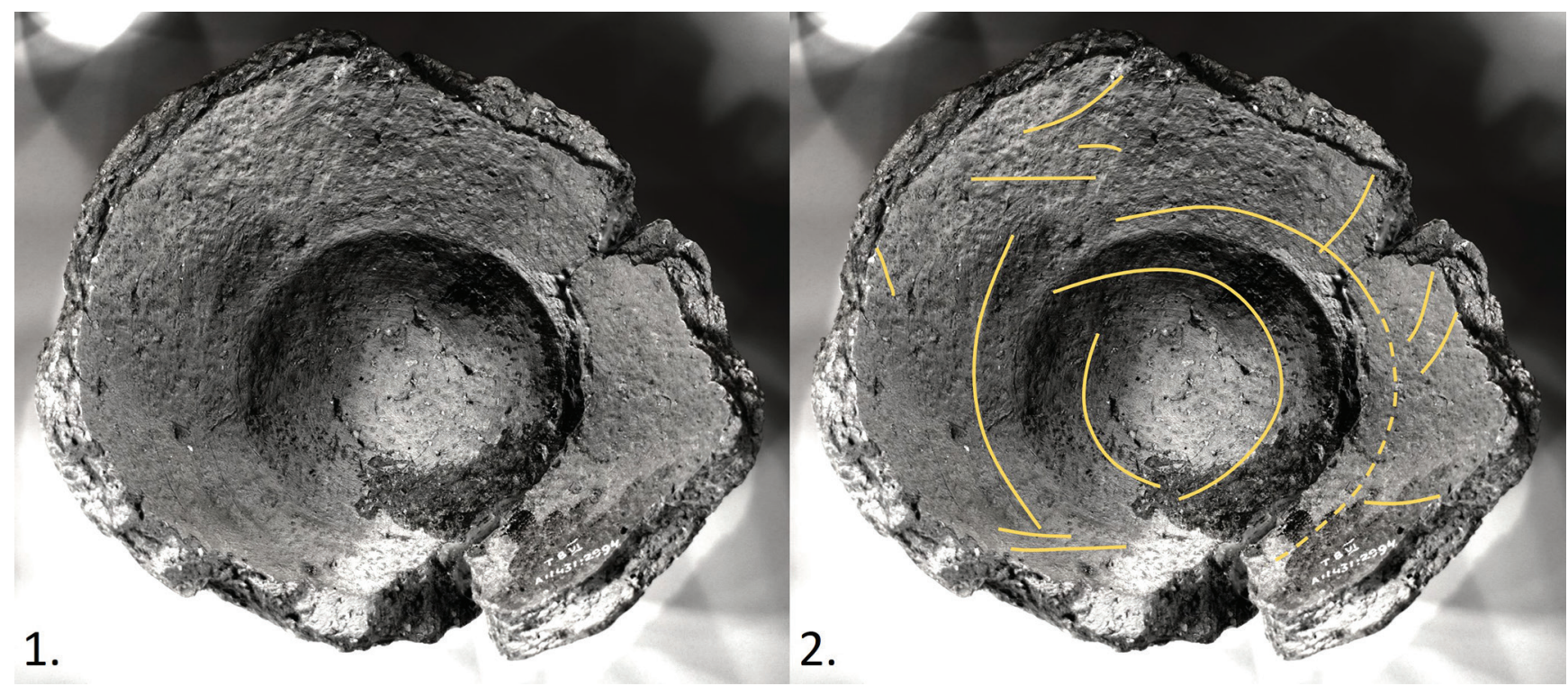

Figure 7. Baltic ware pot bottom in RTIViewer from Talsi hillfort, A 11431:2992.

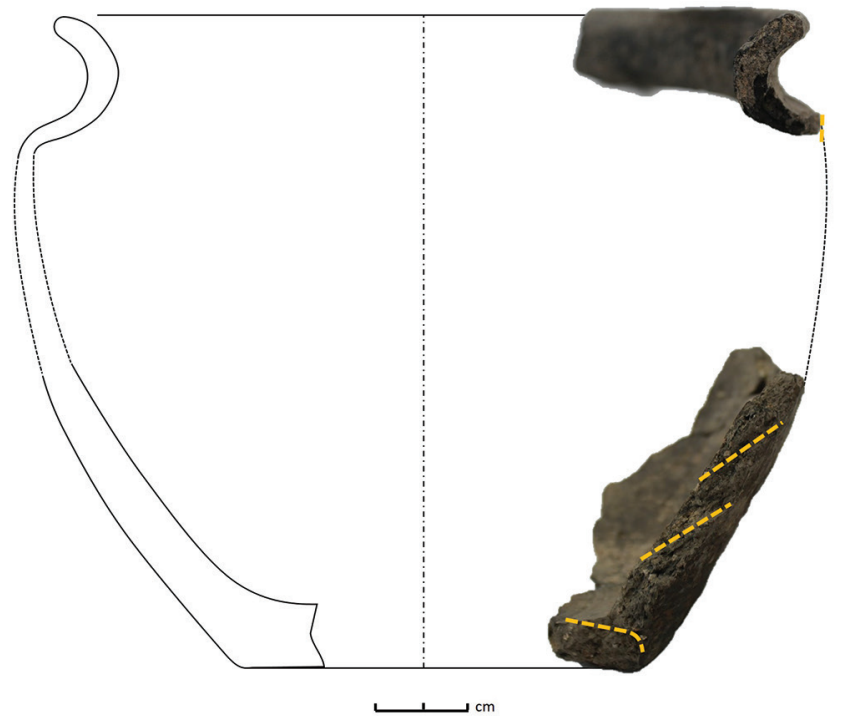

Figure 8. Baltic ware pot reconstruction from Talsi hillfort, A 11431:2918.

\section{Discussion}

The wall thickness and uniformity of the Courland and Daugava archaeological pottery were notably different. Daugava Baltic ware had thin walls $(0.4-0.8 \mathrm{~cm})$ with minimal variation in thickness $(0.1-0.4 \mathrm{~cm})$. The Courland Baltic ware had much thicker walls, with the base being the thickest $(1.1-1.7 \mathrm{~cm})$ and then a gradual thinning out towards the shoulder (down to $0.4 \mathrm{~cm}$ ). The variation in wall thickness was around $0.9 \mathrm{~cm}$.

The difference in wall thickness - and its consistency could be due to many reasons and influencing factors which are often closely related to each other. The main influencing factors are: the material, skill of the potter, pottery traditions, or production methods. It could be observed that the production traces on the Courland vessels were quite

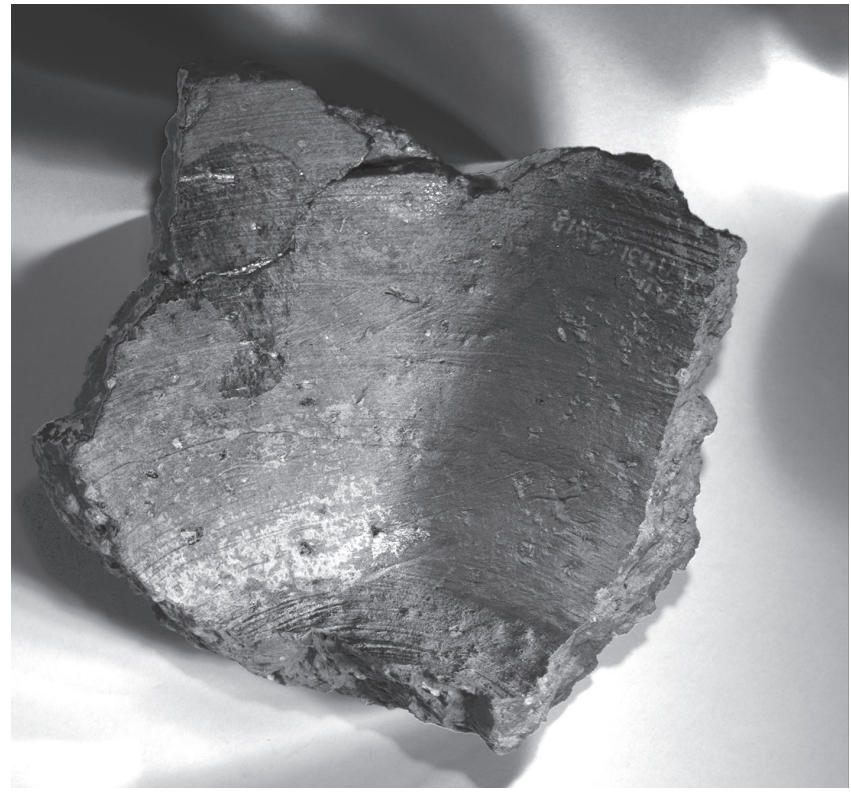

Figure 9. Baltic ware pot bottom in RTIViewer from Talsi hillfort, A 11431:2918.

pronounced - indicating that during the shaping process the clay must have been quite soft. The use of soft clay would have made it much more problematical to create pots with thin walls. However, as noted before, deposits of good quality clay are common in Latvia and the mixture used was not particularly sandy or exhibit other notable factors of poor clay. Hence, the softness of the clay was a choice of the potter, not a restriction placed upon him. This left the skill of the potter, production methods or the general pottery traditions as the most likely reasons. As these are often interlinked, it would not be possible to arbitrarily select just one as being the dominant reason.

On the other hand, pottery from Daugava exhibited surprising wall thinness and consistency. Such uniformly 
thin walls would be difficult to achieve under the best of circumstances. It should be taken as a mark of high quality and an indication of the skill of the potter.

Comparing the coiling technique visible on the fractures of Daugava and Courland Baltic ware with the prepared sample pottery, we could see that in both regions of Baltic ware production the principal coiling technique was similar. In both cases the coils were primarily attached from the inside (Figures 1, 4 and 8). However, the bases of Daugava Baltic ware seemed to be made in a different technique than had been previously assumed. The clay particles were more twisted and warped than the ones in the samples and the bases tended to break in a different pattern (Figures 1 and 4). The bases of Courland Baltic ware seemed to be fashioned as the typical clay disc but had a peculiar braking pattern, which may be attributed to the small sample set but should be considered when doing further research.

Although in both cases the general building up of the pot was done by attaching the coils from the inside, the Daugava Baltic ware bases must have been created by a different technique than we had previously assumed. There are more techniques for creating pot bases recorded in the ethnographic material, but a much larger scale experimental study would be needed to establish which method was used to create this part of the pot. As this unknown factor does not further impede the analyses of the shaping techniques, it will be left as an open question for a more specialised, experimental study.

In both regions the production traces and draglines on pots showed different shaping techniques and the application of the potter's wheel. The production traces on Daugava Baltic ware showed extensive use of the wheel's rotation to shape the whole vessel. This was emphasised by the preservation of the coil connections and potter's finger impressions on the lower parts of the pot. The coiled cylinder had been roughly put together by hand and the potter had not attempted to smooth them out by hand before starting the wheel's rotation. With the rotation of the wheel the pot was shaped, fully evening out and covering these production steps on the top and middle of the pot. As the bottom part did not require as much alteration or stretching, the impressions were left visible. Only the outside surface was fully smoothed out for aesthetic reasons, with the inside left unaltered.

For the Courland Baltic ware, the horizontal draglines were much more focused on the rim. The bottom sherds showed either a rotational movement with frequent interruptions or handmade pottery-shaping techniques. The potter's wheel was beginning to be used to assist in the shaping process - mostly for shaping of the rim. However, the handmade techniques were still used extensively.

Archaeologists have noted that the adoption of the potter's wheel happens gradually and there are several intermediary steps of wheel coiling before the pottery is fully wheel-thrown (Roux and Courty, 1998, pp.748-750; Jeffra, 2011, pp.106106; Rückl and Jacobs, 2016, pp.297-298). Bobrinsky has traced this stepwise adoption of the potter's wheel in his in-depth studies of Slavic pottery. Based on ethnographic material, he separated seven stages of how the potter's wheel had been used in making different types of Slavic pottery (see section 2.2 Methods) (Bobrinsky, 1978, p.27).

Based on this separation and the production traces noted in this study, the Baltic ware of Courland potters seems more in line with the $3^{\text {rd }}$ stage of pottery production. The pots were smoothed out using the potter's wheel and the potter's wheel was used to shape the rim of the vessels. However, the bottoms of the pots were still predominantly shaped by hand. As of the fragmental material and the draglines left from smoothing out the surface, it was difficult to say precisely where on the pot the rotational shaping began. The closest parallel to the more widely-used four methods of wheel coiling by Roux and Courty would be the $1^{\text {st }}$ method (Roux, 2016, p.84).

Daugava potters used the potter's wheel in accordance with Bobrinsky's $4^{\text {th }}$ stage. After the base cylinder was coiled by hand the pot was fully shaped using the rotation of the wheel. The difference between the bottom $1 / 3$ of the pots and top parts of the pots provide an illustration of the rudimentary hand-built cylinder. The closest parallel to the widely-used four methods of wheel coiling could be the $3^{\text {rd }}$ method (Roux, 2016, p.84).

According to ethnographical data from the early to mid-1900s Slavic potters, the difference in the shaping process and the wheel use had an important implication for the professionalisation of the potter (Table 3). In the ethnographical data, no potter working in or above the $4^{\text {th }}$ stage of pottery production (using any type of nonelectrical potter's wheel) had worked for home production or commission. Potters at the $4^{\text {th }}$ stage and above fully intended to sell their wares in the regional (or larger) market. The $3^{\text {rd }}$ stage was the transitionary period where the first production for a local and countryside market appeared (Bobrinsky, 1978 , p.33). In other archaeological contexts, the level of wheel use has also been interpreted to signify a certain level of specialisation (Baldi and Roux, 2016, p.5).

Based on the previously mentioned parallels - the Baltic ware produced in Daugava region already had specialised potters making wares intended for the market. This was also supported by the high quality (and its consistency) of the produced wares. The quality and standardisation of Daugava Baltic ware indicated a level of craft specialisation.

In the examined Courland pottery, these indications were lacking. The ethnographic material shows that the $3^{\text {rd }}$ stage of pottery production was a transitional period. Potters could have been working for commission or for some small to medium-scale market. The quality and features of Courland Baltic ware did not require such a high level of specialisation. The potter could have made pots less frequently or not invested as much initial time honing their skills.

Another question-did the difference in production methods seen imply a difference in the tools that the potters used? In ethnographic material (1900s), Western Slavic potters had used six different types of non-electric pottery wheels: four versions of the hand-driven wheel and two versions of the foot-driven wheel (Figure 10) (Bobrinsky, 1962a, pp.34-44; 
Table 3. Production and trade practises of traditional Slavic potters in the 1900s from Bobrinsky, 1978, pp.29-33.

\begin{tabular}{|c|c|c|c|}
\hline $\begin{array}{c}\text { Technique used } \\
\text { (according to the stages) }\end{array}$ & Wheel used & Distribution model & Setting of distribution \\
\hline 0 & handmade & commission & - \\
\hline 0 & handmade & commission & - \\
\hline 0 & handmade & commission & - \\
\hline 0 & handmade & commission & - \\
\hline 0 & handmade & commission & - \\
\hline 0 & handmade & commission & - \\
\hline 0 & handmade & local market & city regions \\
\hline 3 & hand dr. wheel - light & commission & - \\
\hline 3 & hand dr. wheel - light & commission & - \\
\hline 3 & hand dr. wheel - light & local market & countryside \\
\hline 3 & hand dr. wheel - light & local market & countryside \\
\hline 3 & hand dr. wheel - light & local market & countryside \\
\hline 3 & hand dr. wheel - light & regional market & countryside \\
\hline 3 & hand dr. wheel - light & regional market & countryside \\
\hline 4 & foot dr. wheel - carusel & regional market & countryside \\
\hline 4 & hand dr. wheel - light & regional market & countryside \\
\hline 4 & hand dr. wheel - light & regional market & countryside \\
\hline 4 & hand dr. wheel - light & regional market & countryside \\
\hline 5 & foot dr. wheel - spinning top & local market & city regions \\
\hline 5 & hand dr. wheel - heavy & local market & city regions \\
\hline 5 & foot $\mathrm{dr}$. wheel - spinning top & city market & countryside \\
\hline 5 & hand dr. wheel - light & city market & countryside \\
\hline 6 & foot dr. wheel - spinning top & local market & city regions \\
\hline 6 & foot dr. wheel - spinning top & city market & countryside \\
\hline 6 & hand dr. wheel - heavy & city market & countryside \\
\hline 6 & foot dr. wheel - spinning top & city market & countryside \\
\hline 6 & foot dr. wheel - spinning top & city market & countryside \\
\hline 6 & foot dr. wheel - spinning top & city market & countryside \\
\hline 7 & foot dr. wheel - spinning top & local market & city regions \\
\hline 7 & foot dr. wheel - spinning top & city market & countryside \\
\hline 7 & foot $\mathrm{dr}$. wheel - spinning top & city market & countryside \\
\hline 7 & foot dr. wheel - spinning top & city market & countryside \\
\hline 7 & foot dr. wheel - spinning top & city market & countryside \\
\hline 7 & foot $\mathrm{dr}$. wheel - spinning top & city market & countryside \\
\hline 7 & foot dr. wheel - spinning top & city market & countryside \\
\hline 7 & foot dr. wheel - spinning top & city market & countryside \\
\hline$?$ & hand dr. wheel - light & local market & countryside \\
\hline$?$ & foot dr. wheel - spinning top & city market & countryside \\
\hline$?$ & foot dr. wheel - spinning top & city market & countryside \\
\hline$?$ & foot dr. wheel - carusel & city market & countryside \\
\hline$?$ & foot dr. wheel - spinning top & city market & countryside \\
\hline$?$ & foot dr. wheel - spinning top & city market & countryside \\
\hline$?$ & foot dr. wheel - spinning top & city market & countryside \\
\hline
\end{tabular}


Table 3. Production and trade practises of traditional Slavic potters in the 1900s from Bobrinsky, 1978, pp.29-33. (Continuation)

\begin{tabular}{cccc}
\hline $\begin{array}{c}\text { Technique used } \\
\text { (according to the stages) }\end{array}$ & Wheel used & Distribution model & Setting of distribution \\
\hline$?$ & hand dr. wheel - heavy & city market & countryside \\
$1 ?$ & hand dr. wheel - light & commission & local market \\
$3 ?$ & hand dr. wheel - light & local market & countryside \\
$3 ?$ & hand dr. wheel - light & regional market & countryside \\
$4 ?$ & foot dr. wheel - carusel & city market & countryside \\
5 or 6 & hand dr. wheel - light & regional market & countryside \\
5 or 6 & hand dr. wheel - heavy & city market & countryside \\
$5 ?$ & hand dr. wheel - light & city market & countryside \\
$5 ?$ & hand dr. wheel - heavy & city market & countryside \\
$6 ?$ & foot dr. wheel - spinning top & city market & countryside \\
$6 ?$ & hand dr. wheel - heavy & city market & countryside \\
$7 ?$ & foot dr. wheel - spinning top & local market & city regions
\end{tabular}

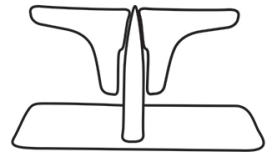

1. $\underbrace{0}$ $20 \mathrm{~cm}$

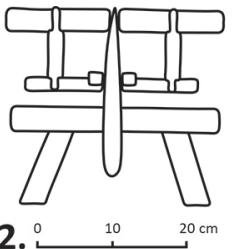

2.

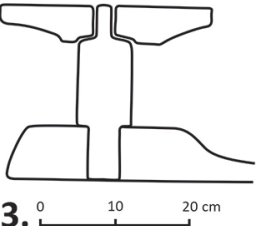

3. ㄴ.

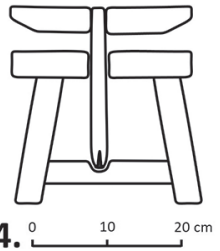

Figure 10. Slavic potter's wheels from Bobrinsky, 1962, pp.35-44.

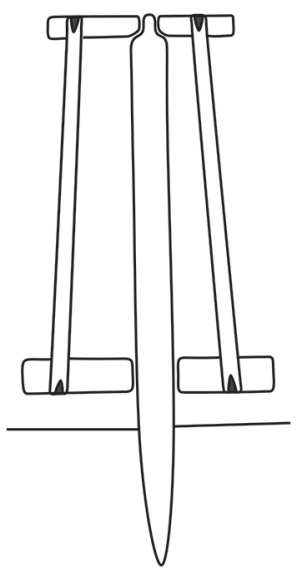

5. $\underbrace{10} \quad 20 \mathrm{~cm}$

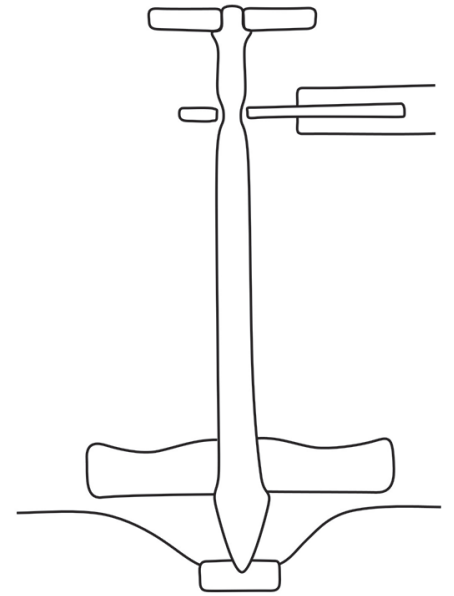

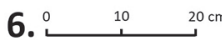

Bobrinsky, 1962b, p.38; Griežienè, ed., 2011, pp.16 and 19; Bobrinsky, Melnikovskaja, 1977, p.177; Bobrinsky, 1991, pp.37-48; Djukanović, 2011; Zelenin, 1991, pp.132-135). In the $10^{\text {th }}-13^{\text {th }}$ century material of Pskov and Novgorod, archaeologists have identified fragments that they link to five of these wheel types: mushroom type; turntable; hand-driven potter's wheel with a fixed axis; foot-driven pottery wheel of the carousel construction; and foot-driven pottery wheel with a flywheel (Bobrinsky, 1962, pp.47-52; Plohov and
Sorokin, 2006, pp.107-108). Any of these potter's wheels could have been used in the Baltic region. However, without direct archaeological evidence it would be questionable to argue for the use of one potter's wheel construction to the exclusion of the others.

It is impossible to clearly say if Daugava potters used one type of potter's wheel while the Courland potters used another type of wheel. What the production traces do suggest is that the Daugava potters had used potter's wheels with 
enough inertia to fully shape the clay and produce consistent draglines. The draglines visible on the pottery indicate a sufficiently large rotational inertia to resist the drag produced by the potter's fingers for several rotations.

Inertia is not intrinsic to one or two construction types of a potter's wheel. It is a property that relates to the mass and radius of the potter's wheel. Hence, both foot and hand potter's wheels could have been constructed to produce enough inertia to leave the draglines seen on the Daugava Baltic ware. In this case, to provide the needed inertia, it should either be a hand-driven potter's wheel of a reasonably large radius - or a foot-driven potter's wheel that has a flywheel with enough mass/radius. As such consistent draglines are not found on Courland Baltic ware, Courland potters could have used a wheel with a smaller radius, but this is not an essential requirement.

\section{Conclusions}

Baltic ware pottery, in the lower reaches of Daugava and Courland, was in both cases wheel-coiled ceramics. In both cases the coils were primarily attached from the inside. The pot bases of Daugava pottery were made in a technique that did not align with previous assumptions. A large-scale experimental study would be needed to narrow down the possibilities and conclude which technique was used to produce the bases.

Many other technological features of the Baltic ware pots in the two regions differed. The pots varied in wall thickness and its evenness as well as in some production traces. The difference in the Daugava and Courland Baltic ware seemed to be based on the extent to which the potter's wheel was used. According to production traces, the Daugava potters used the wheel more extensively than the Courland potters. Using the system of stages of potter's wheel use by Bobrinsky - the Daugava potters operated in the $4^{\text {th }}$ stage of pottery production, while Courland potters operated in the $3^{\text {rd }}$ stage of pottery production.

Courland potters were still focusing on the techniques used in handmade pottery. During the construction of the body, they attached and evened out the coils without notable use of the wheel's rotation. The potters used the wheel's rotation to shape the profile of the rim/neck and to smooth out the surface of the vessel. Based on ethnographic material, this mode of production correlates with a production for commission or for the local and countryside markets.

Daugava potters used the potter's wheel more extensively. They coiled a rudimentary cylinder by hand, but then further on they relied on the potter's wheel. They used the wheel's rotation to even out the coils, shape the pot and smooth out its surface. Based on ethnographic material, this mode of production correlates with a production for the countryside market. The ethnographical data taken, together with the quality and consistency of the produced wares by Daugava potters, suggests a level of professionalisation for the Daugava potters.
There is still the open question as to whether the difference was in the potter's skill alone or also in the tools they used. The $4^{\text {th }}$ stage of pottery production required a potter's wheel with sufficient inertia to withstand the drag of the potter's fingers to fully shape a medium-sized pot. The $3^{\text {rd }}$ stage of pottery production did not require as much inertia. The shaping was done only at the rim part and hence the potter could have used a lighter wheel construction. However, this does not necessarily mean that, indeed, it was a lighter wheel construction. The difference could still be simply in the traditions, professionalism, and the skill of the potter.

\section{Acknowledgements}

This article was created with the support of the National History Museum of Latvia. We are also grateful to the anonymous reviewers who showed interest in our work and made helpful comments to improve our manuscript.

\section{References}

ASARIS J., 2001. Talsi - from Curonian Central Place to Medieval Town. In: M. Auns, ed. Lubek style? Novgorod style? Baltic Rim central places as areas for cultural encounters and urbanisation 1100-1400 $A D$, transactions of the central level symposium of the Culture Clash or Compromise (CCC) project held in Talsi September 18-21 1998. Vol. 3. Riga: Nordik, pp. 69-75.

ASARIS, J., MUIŽNIEKS, V., RADIN̦Š, A., VIRSE, I., ŽEIERE, I., 2008. Kurši senatnē. Couronians in antiquity. Rīga: Latvijas Nacionālais vēstures muzejs.

ASARIS, J., TORA., A., 1994. Pētījumi Talsu senpilsētā. In: Ē. Mugurēvičs, ed. Zinātniskās atskaites sesijas materiāli par arheologu 1992. un 1993. gada pētījumu rezultātiem. Rīga: Latvijas Vēstures institūta apgāds, pp. 19-22.

BALDI, J., ROUX, V., 2016. The innovation of the potter's wheel: a comparative perspective between Mesopotamia and the southern Levant. Levant, 48(3), 1-18.

BERG, I. 2020, pre-print. The Potter's Wheel. In: Encyclopaedia of Global Archaeology. Springer, pp. 1-13.

BOBRINSKY, A.A., 1962a. Drevnerusskij Goncharnyj Krug. Sovetskaja Arheologija, 3. 33-52.

BOBRINSKY, A.A., 1962b. K Izucheniju Tehniki Goncharnogo Remesla na Territorii Smolenskoj Oblasti. Sovetskaja Arheologija, 2. 31-50.

BOBRINSKY, A.A., 1978: Goncharstvo Vostochnoj Evropy: istochniki i metody izuchenija. Moskva: Nauka.

BOBRINSKY, A.A., 1991: Goncharnye Masterskie i Gorny Vostochnoj Evropy. Moskva: Nauka.

BOBRINSKY, A.A., MELNIKOVSKAJA, O.N., 1977. Goncharnyj Krug u Poselenija Juhnovskij Kultury. Sovetskaja Arheologija, 2, 172-180.

CHI, 2020. Reflectance Transformation Imaging (RTI). [online]. Cultural heritage imaging. [viewed 07/12/2020]. Available from: http:// culturalheritageimaging.org/Technologies/RTI/.

DJUKANOVIĆ, V., 2011. PEKVA: Large Hand-Wheeled Pottery Lid for Covering Bread During Baking. [online]. Conference: Traditional Pottery Making from The Ethnoarchaeological Point of View. Scientific Research and Safeguarding of Intangible Heritage. National Museum in Belgrade. $10^{\text {th }}$ to $12^{\text {th }}$ June 2011. [viewed 07/12/2020]. Available from: http://narodnimuzej.rs/conference2011/wp-content/uploads/2011/02/V.Djukanovic_PEKVA-\%E2\%80\%93-LARGE-HAND-WHEELEDPOTTERY-LID-FOR-COVERING-BREAD-DURING-BAKING.pdf

DUMPE, B., 2007. Agrā neolīta keramikas rekonstrukcijas. In: I. Stašulāne, ed. Latvijas nacionālā vēstures muzeja lasījumi 2004.-2006. Latvijas Nacionālā vēstures muzeja raksti Nr.12. Rīga: N.I.M.S. pp. 25-44. 
DUMPE, B., 2009. Senās podniecības krāsnis Latvijā. In: Pa Somugru Pēdām Baltijas Jūras Krastā. Starptautiskās zinātniskās konferences materiāli. 2009. gada 23.aprīlis, Turaida. Rīga: Zinātne. pp. 65-75.

DUMPE, B., 2021. Trauki. In: I. Stašulāne, ed. Latvijas Arheologijas Rokasgrāmata. Rīga: Zinātne. pp. 493-509.

EITELJORG, H., 1980. The Fast Wheel, the Multiple-Brush Com-pass, and Athens as Home of the Protogeometric Style. American Journal of Archaeology, 84(4), 445-452.

GRIEŽIENĖ, A., ed., 2011. Tradicinès keramikos dirbiniu formos, dekoras, gamyba ir išdegimas. Vilnius: S. Jokužio leidykla-spaustuvè.

GUNNARSSONE, A., ORAS, E., TALBOT, H.M., ILVES, K., and LEGZDIN̦A, D., 2020. Cooking for The Living and The Dead: Lipid Analyses of Rauši Settlement and Cemetery Pottery from the $11^{\text {th }}-13^{\text {th }}$ Century. Estonian Journal of Archaeology, 24(2), 45-69.

JEFFRA, C.D., 2011. An Experimental Approach to the Pottery Wheel in Bronze Age Crete and Cyprus. Unpublished thesis (PhD). University of Exeter.

KRAUKLE, R., 2011. Talsu pilskalns 10.-15. gadsimtā. Unpublished thesis (M.A.). University of Latvia.

KURŠS, V., STINKULE, A., 1972. Māli Latvijas zemes dzīlēs un rūpniecībāa. Rīga: Izdevniecība "Liesma".

PILIČIAUSKAS, G., 2018. Virvelinès keramikos kultūra Lietuvoje 2800 2400 cal BC. Vilnus: Lietuvos istorijos institutas.

PLOHOV, A.V., SOROKIN, A.N., 2006. Detali Goncharnyh Krugov s Gribovidnym Diskom iz Raskopok v Novgorode. In: V.L. Janin, ed. Novgorod $i$ Novgorodskaja Zemlja. Istorija $i$ arheologija. $20^{\text {th }}$ ed. Velikij Novgorod. pp. 105-114.

RICE, P.M., 2005. Pottery Analysis: A Sourcebook. Chicago: University of Chicago Press.

ROUX, V., 2016. Ceramics and Society. A Technological Approach to Archeological Assemblages. Paris: Springer.

ROUX, V., COURTY, M.A., 1998. Identification of Wheel-Fashioning
Methods: Technological Analysis of $4^{\text {th }}-3^{\text {rd }}$ Millennium BC Oriental Ceramics. Journal of Archaeological Science, 25(8), 747-763.

ROUX, V., DE MIROSCHEDJI, P., 2009. Revisiting the history of the potter's wheel in the Southern Levant. Levant, 41(2), 155-173.

RÜCKL, Š., JACOBS, L., 2016. "With a Little Help from My Wheel": Wheel-Coiled Pottery in Protogeometric Greece. Hesperia: The Journal of the American School of Classical Studies at Athens, 85(2), 297-321.

STINKULE, A., 2014. Māli Latvijas Zemes dzīlēs. Rīga: RTU izdevniecība.

ŠULTE, A., 2011. Talsu un Padures pilskalna keramika. Unpublished thesis (B.A.). University of Latvia.

ŠULTE, A., GUNNARSSONS, D.S.E., 2017. Ieskats Salaspils Laukskolas apmetnes kapulauka un keramikas telpiskajā analīzē. In: I. Antēna, ed. Latvijas Nacionālā vēstures muzeja zinātniskie lasījumi 2014.2016. Latvijas Nacionālā vēstures muzeja raksti Nr.23. Rīga: Latvijas Nacionālais vēstures muzejs. pp. 11-20.

TVAURI, A., 2000. Pihkva Pottsepad Viljandis ja Tartus 13. Sajandil. Estonian Journal of Archaeology, 4(1), 21-38.

VALTERS, A., ed., 1992. Fizika. Rīga: Zvaigzne.

VASKS, A., KALNINA, L., and DAUGNORA, L., 2011. Beltu pilskalns. Arheologija un etnogrāfija, 25, 73-99.

VISOCKA, V., KALNIN̦Š, M., KONS, A., 2021. Resursu apzināšana arheologijas kontekstā: māli Daugavas lejtecē, Kurzemē un Burtnieka ezera apkārtne-/ Survey of the resources in the context of archaeology: clays in the lower Daugava area, the Kurzeme region and the surroundings of Lake Burtnieks. In: A. Vilcāne, ed. LU 79. starptautiskās zinātniskās konferences sekcija: Arheologu un etnogrāfu pētījumi Latvijā 2018.-2020. Conference proceedings, $11^{\text {th }}$ March 2021. Riga: University of Latvia, pp. 12-13.

ZARIN̦A, A., 2006. Salaspils Laukskolas kapulauks 10.-13. gadsimts. Rīga: Latvijas Vēstures Institūta Apgāds.

ZELENIN, D.K., 1991. Vostochnoslavjanskaja jetnografija. Moskva: Nauka. 